\title{
Serving Nigerian Law Students: E-readiness and Utilization of University E-Information Facilities
}

\author{
B.J Mostert, D.Y Olorunfemi \\ Department of Information Studies \\ University of Zululand \\ South Africa
}

\begin{abstract}
During the last few years Nigeria invested substantially in their ICT infrastructure. Nigerian university libraries have acknowledged the need for the introduction of ICTs and e-resources for information retrieval. For a law faculty to exist a law library with e-resources is a requirement. The study aimed to determine the current position concerning the ability of the university and academic law libraries to provide access to ICTs and e-resources as part of their information service delivery. A secondary aim was to determine the e-readiness of the law students to search, retrieve and utilize $e$ resources. Twelve universities offering law were targeted. Interviews were held with the librarians from both the university and law libraries and student opinions were sought through questionnaires and observation. One thousand two hundred and sixty students responded to the questionnaires. Observations of the available ICT facilities were also made. It was found that ICTs are available, but that the infrastructure is insufficient in most of the libraries. It was found that the university libraries were better resourced with ICTs than the academic law libraries. E-resources were also available in some of the law libraries, but not in all. Inaccessibility to ICTs was a major challenge. Many other challenges were identified impacting on service delivery and information seeking. Students were mostly e-ready but lacked general awareness of and easy access to e-resources. It was recommended that all law libraries improve on their ICT facilities and provision of e-resources. Also that the university managers actively search for ways to minimize disruptions such as erratic power supplies, low bandwidth, lack of computers, and payment of fees for Internet access.
\end{abstract}

\section{Introduction}

E-readiness presupposes that Information Communication Technology infrastructure is in place to support e-services. Having identified ICT as a key factor in economic development, Nigeria has invested large financial inputs in improving the current infrastructure over the past few years.
Nigeria is a West African country with a population of over 151 million people making it the most populated country in Arica. In terms of development the country is a developing country, battling low income rates, high levels of poverty and illiteracy. Library development in the country has been very slow with the government not providing enough funding or support to develop them. University libraries are generally the most developed of all the library types in the country [1]. In 2001, the National Policy for Information Technology was adopted, aiming at developing ICT in the country. An agency to implement the use of information technology in education, The National Information Technology Department Agency, was established with the particular aim to introduce information technologies that can be used within and between Nigerian universities. Though this project eventually failed, many of the libraries managed to introduce ICTs as part of their service delivery [1].

To determine the e-readiness of libraries to utilize or provide ICTs for service delivery to their users, it is important to first establish whether the underlying ICT infrastructure is in place to support such endeavors.

The Federal Ministry of Communication Technology has recently announced that, by 2015 , the country wants to connect the whole of Nigeria by providing a ubiquitous and cost effective national ICT infrastructure [2]. To date Nigeria has made great progress in the development of a national fiberoptic network by way of attracting private investment into the project. Though these private investors were not interested to extend the cables to rural areas, the government is now able to tap into the backbone set by the private sector to extend the network to the more out-laying areas [3]. In 2012 France Telecom-Orange and the members of the Africa Coast to Europe (ACE) consortium announced that Nigeria will be connected in 2013 to the ACE submarine cable. This cable will provide connectivity to broadband internet in Africa and will also add extra capacity to existing international networks [4].

The greatest indicator of the role of technology in economic development lies in the formulation of relevant telecommunication and IT policies, as well as the empowerment of an independent regulator for 
the sector. To this effect the Nigerian Communications Commission was constituted to regulate the industry and take responsibility for the development of and ICT infrastructure for the country. Additional actions undertaken by the government included the liberalization and privatization of the ICT industry, the issuing of unified licenses, and collaboration with foreign governments such as China and Korea. The launch of a communication satellite, The Nigerian Communication Satellite, by the Chinese has raised high expectations among the local population as it is expected that it would revolutionize telecommunications, and provide Internet access to even the most remote Nigerian village [5].

In 2006 a Presidential Task Force was given the mandate study existing telecommunications and ICT structures, and also to recommend an institutional framework that could result in more efficient and effective cooperation between stakeholders responsible for the making of policies, regulations and the implementation of government policies in the telecommunications and ICT sector [6].

Over the last few years phenomenal growth was experienced in the Nigerian telecommunications industry. In 2011 Foster and Pushak [3] reported that by 200970 percent of the Nigerian population was living within the rage of the Global System for Mobile Communications (GSM) signal. In 2013 the Ministry of Communication Technology announced the fixed line access has risen with $0.51 \%$ in 2011 and $1.5 \%$ in 2012 , while mobile subscriptions increased from $68.49 \%$ in 2011 to $71.54 \%$ in 2012. Mobile phone coverage in rural areas reached $40 \%$ in 2012, while the speed of broadband access improved from 1.0 in 2011 to 1.8 in 2012. The cost of broadband subscription was also significantly reduced [2]. The introduction of mobile telephony has been characterized by their low cost, lower tariffs, as well as the incentives that were being offered to first time users. The majority of mobile phone users opted for the pre-paid option because of among others its low start-up cost [6]. According to Uzor [7] the level of ICT uptake is slowly growing with a reported growth of $0.18 \%$ between 2010 and 2011. According to a report by the International Telecommunications Union (ITU) [8], Nigeria, as of 2011, ranked 122 out of 155 countries in terms of the ICT Development Index (IDI).

However, despite the knowledge that ICT can play a considerable role in service delivery, most university libraries have not yet fully embraced its potential [9].

\section{E-readiness of Nigerian university libraries}

In Nigeria today, many of the universities are incorporating ICTs into their programs both in the administrative work and in terms of the teaching and learning process in line with the aims and objectives of the universities. For example, many universities in Nigeria are now conducting their admission process through the use of electronic programmed examinations to determine the competence of the applicants. The universities now expect the incoming students to have basic ICT skills before admission into the universities.

The University libraries on the other hand have been relatively slow in their uptake of, and the provision of access to networked facilities and eresources. The automation of some in-house library functions and services, such as computer-generated bibliographic and serials lists, though introduced in some libraries by 1975 is yet to become the norm in most of the university libraries, though Integrated Library Systems are slowly being introduced. A study by Krubu and Osarawu [10] on the impact of ICTs in Nigerian Universities found that library automation, in the libraries that have already introduced it, was seen as a positive contributor to service delivery. The fact that modern Integrated Library Systems are mainly web-based has resulted in a number of the university libraries that have established a web-presence. Additional to these some of the libraries have embarked on digitizing their local holdings [1].

\section{Law education in Nigeria}

The National Universities Commission (NUC) is the National regulatory body for all Nigerian universities, setting the general standards for academic programs and courses offered and also responsible for the issuing of licenses for the establishment of new universities in Nigeria. The minimum entry qualification requirements for admission into a university in Nigeria is a five credit pass in Senior Secondary Certificate of Education/General Certificate of Education (SSCE/GCE O/L) ordinary level with English and Mathematics as compulsory for almost all courses in Nigerian universities. The Unified Tertiary Matriculation Examination (UME) is the general entrance examination normally written by all candidates seeking admission into universities, polytechnics or college of education. An additional pre-admission screening examination determines the eventual entry into the applicant's program and university of choice. The law degree is a five year degree, of which the fifth year consists of compulsory attendance to the Law School where the practical aspects of the legal profession is being taught [11].

The Nigerian Council of Legal Education approves the curriculum of the law degrees offered by Nigerian universities, and commonly consist of subjects such as Constitutional Law, Criminal Law, 
Law of Contract, Law of Tort, Land Law, Equity \& Trust, Commercial Law, Law of Evidence, English law, English Courts system, English legal system, Indigenous law, Islamic law, Customary law, Administrative law, Jurisprudence, International law, and Private law [12].

Thirty public universities and 4 private universities in Nigeria offer law. A prerequisite for any university to be allowed to offer a law program is the existence of a separate law library which, as part of their service delivery, provides access to an electronic library. Law students, thus, have access to two libraries on campus to utilize for information seeking. However the university libraries are mostly fulfilling a supporting role as all dedicated law information sources are kept in the law libraries.

As part of an effort to connect students whose law libraries cannot afford to subscribe to databases, the National University Commission has made available to the university libraries a portal to a virtual library providing access to a number of databases, among them Law databases. A user ID and a pass word obtainable from each university library are required to access the website.

\section{Aim and objectives}

University library systems have all greatly invested in providing the necessary ICT infrastructure to support e-information services. Additionally, some significant investments have been made in digitizing existing print materials, and also in procuring or subscribing to e-resources. The same cannot be said about the law libraries, which seem to be at various stages of introducing ICTs into their libraries. Nigerian students, in general, seem to have embraced the utilization of ICTs to access information resources, however, not much is known about their real capability of retrieving required documents. The aim of this study was therefore to determine the e-readiness of Nigerian university libraries, and in particular the law libraries who are dedicated to serve the law students, to deliver services to law students, and also to establish the readiness of the students to use such facilities. The objectives included:

- To establish the current status of Nigeria's ICT infrastructure

- To determine the e-readiness of Nigerian universities to provide information services to law students

- To establish the ability of law students to effectively search and retrieve legal information

\section{Methodology}

A survey was used to conduct the study. A mixed method approach was used in the design of the instruments as it was deemed imperative to illicit both quantitative and qualitative information. The study targeted three populations, i.e. public universities offering law, the library staff (both university and law library staff), and the law students. The reason for choosing only public universities is the fact that the regulatory structures and the funding models at the private universities differ from the public libraries which are regulated and funded by the Nigerian government. Twelve public universities were selected using convenience sampling. This was done as the universities are widespread over the country and travelling to the farour areas are extremely difficult due to a lack of infrastructure. It was also assumed that the twelve universities would represent the population as a whole. In each of the universities the University Librarians, as well as the law library librarians were purposively selected to be interviewed. The law student population at the twelve universities was 7219. Twenty per cent of the students at each university (1534) were targeted of which 1260 (82\%) responded to the questionnaire handed out to them. The questionnaire aimed at specifically determining the utilization of the law libraries since these facilities are dedicated to servicing this specific student population. A small group of students (100) were observed to ascertain whether they could actually find information using the available eresources. Observation was also used to determine the web presence of the libraries and to determine the available e-resources available through the web.

\section{Findings}

\subsection{ICT infrastructure on campuses}

Basic ICT infrastructure seemed to be available on most of the campuses surveyed. Commonly found hardware included: computers, laptops, broadband radio, electronic security systems, and bandwidth for e-communication and the Internet. The librarians commented that the availability of wireless networks enabled a wide area to be covered, thereby allowing students to access the Internet anywhere on campus. Security of the network was also in place. Also, virtual integrated library systems were installed in most libraries which allowed seamless service delivery. The libraries that had a website were all very positive about its effect on service delivery. However, lack of sufficient bandwidth resulted in the server not being able to handle the huge volumes of traffic during the day, thus leading to very low Internet downloading speeds. The download speed, 
however, improved early in the mornings and in the evenings.

Of the 12 law libraries, only 1 had a web presence, while among the university libraries, 10 had a web presence. Despite having a website, only 1 law library and 2 university libraries provided access to e-resources. In the case of the law library access was provided to the National University Commission's virtual library, but a user ID and password was required to access it. At the time of the study the passwords were not yet ready to be provided to the law faculty staff and students.

\subsection{ICT availability in the libraries}

ICTs available in the libraries are mostly funded by either the government or the university management. Some of the ICTs were also donated either by an organization or by individuals. Sometimes the libraries generated funding internally to acquire required ICTs.

ICTs commonly found within the libraries were found to be computers (desktops and laptops), Internet facilities, digital law libraries, both subscribed and Open Access databases, CR-ROM databases, fax machines and photocopy machines. Databases commonly found in the university libraries include: Ebscohost, e-Granary, JSTOR, MLA (Modern Language Association) style guide, HINARI Access to Research in Health Programme, OARE (Online Access to Research in the Environment), Commercial law reports, Hein Online, and AGORA (Access to Global Research in Agriculture). Within the law libraries the database choices were much more limited providing access mostly to law databases. Only 7 law libraries indicated that they provided access to databases. These databases included: Westlaw, Lexis-Nexis, Compulaw, Ebscohost, Legalpedia and Law Pavillion. One library provided a database off-line using CD-ROMs.

The available computers within the university libraries ranged from a minimum of 30 computers to a maximum of 420 . Among the law libraries, it was found that the number of computers available to students varied from $2-120$ with a mean of 25 . However, two of the law libraries did not have any computers available.

Internet access is provided on an Internet café principle which requires students to pay N50 (Nigerian Naira) per hour to use the Internet and N10 to print any document from the Internet. A maximum of two hours per student is allowed in order to provide all other students an equal opportunity to use the facilities.

Challenges mentioned by the librarians hampering their service delivery to the students included too few access points, from which students can access the Internet and available e-resources, bandwidth being too low, regular power outages and no standby generator to provide the power required for lighting the library or powering the computers, the lack of space to provide proper ICT facilities, the lack of technical skills as well as technical staff to assists if problems are experienced, the lack of qualified human capital to support and train students to utilize especially the Internet effectively, and a lack of maintenance culture.

\subsection{Efficiency of ICTs for user utilization}

The students were asked to rate their experiences concerning the utilization of the availble ICTs in the law libraries. This was asked to determine whether availability of ICTs necessarily means that it is accessible for utilization, and if so whether there were any impeding factors in using the available resources.

Table 1 shows the opinions of the law students concerning ICT efficiency.

Table 1. ICT efficiency $\mathrm{N}=1260$

\begin{tabular}{|l|c|c|c|c|}
\hline Option & $\begin{array}{l}\text { Very } \\
\text { good }\end{array}$ & Good & Bad & $\begin{array}{l}\text { Non } \\
\text { exis- } \\
\text { tent }\end{array}$ \\
\hline Accessibility & 202 & 315 & 244 & 499 \\
\hline Availability & 161 & 349 & 247 & 503 \\
\hline $\begin{array}{l}\text { Connection } \\
\text { speed }\end{array}$ & 105 & 232 & 288 & 635 \\
\hline $\begin{array}{l}\text { Downloading } \\
\text { speed }\end{array}$ & 103 & 299 & 304 & 554 \\
\hline $\begin{array}{l}\text { Quality of } \\
\text { hardware }\end{array}$ & 131 & 351 & 193 & 585 \\
\hline
\end{tabular}

The results show that though a sizable number of the respondents felt positive about the fact that ICTs are available and accessible within their law libraries the majority had negative experiences. Of concern are the large numbers indicating that ICTs do not exist at their libraries (503) and if it does exist experienced it as largely inaccessible (244). In terms of Internet access, those that rated the connection and downloading speed as either "very good" or "good" were in the minority compared to those who indicated that it was "bad". Though the quality of the available hardware were indicated as either "very good" or "good" by a number of the respondents (131 and 351 respectively) the majority of the respondents once again either had a negative experience (193) or had no ICTs available to them (585). This sentiment was also echoed by two of the librarians who indicated that some of the hardware in their libraries was outdated and needed replacement. However, the majority of the librarians indicated that they were mostly satisfied with the quality of their hardware.

Accessibility to the ICTs, especially the computer and internet facilities are also hampered by the fact 
that the majority of the university and law librarians indicated that their opening hours were relatively restrictive. The majority indicated that their opening hours were from $8 \mathrm{~h} 00$ till $18 \mathrm{~h} 00$ on weekdays, with only a few opening till $22 \mathrm{~h} 00$. The exception was the University of Ibadan's library which stays open for 22 hours a day. Saturdays most of the libraries operate from $9 \mathrm{~h} 00$ to $14 \mathrm{~h} 00$, with only a very few opening on Sundays.

\subsection{Utilization of ICTs}

The librarians indicated that as staff they mainly used it to do the cataloguing of new information sources and to disseminate this information via their OPAC (Online Public Access Catalogue) to the users. They also used it to provide access to the CDROM collections that they had available, to facilitate access to the Internet for the students and also to use it as a means of providing access to the e-resources that some of the libraries have acquired or digitalized themselves.

The students indicated that they mainly used the available ICTs to access the Internet, the databases and the digital law library. The results are shown in Table 2.

Table 2. Student ICT utilization $\mathbf{N}=1260$

\begin{tabular}{|l|r|r|}
\hline ICT & Responses & $\%$ \\
\hline Internet facilities & 250 & 20 \\
\hline Email & 148 & 12 \\
\hline Digital law library & 110 & 9 \\
\hline Law databases & 107 & 8 \\
\hline CD-ROM Database & 68 & 5 \\
\hline Fax & 54 & 4 \\
\hline Other (Specify) & 8 & 1 \\
\hline
\end{tabular}

From the above table it is clear that access to the Internet is the main reason for utilizing the law libraries, while using it to send e-mails was the second most popular choice. Those who indicated that they use "other" options used the photocopy machines, their mobile phones or their own laptops within the law libraries in order to access information. The overall low utilization of the ICT facilities, especially the law databases (110) and eresources found in the digital libraries (107), has been an unexpected finding as it can be assumed that law students should be encouraged and taught to use these valuable information sources. It however does not seem to be the case. Alternatively it can be an indication that these sources are just not as readily available to law students as would be expected.

\subsection{Challenges experienced in utilizing ICTs}

The respondents were asked to indicate what challenges they experienced in using the available ICTs. Only 596 respondents answered this question. Table 3 summarizes their comments.

\section{Table 3. Challenges experienced in ICT} utilization in the law libraries $\mathrm{N}=596$

\begin{tabular}{|l|r|r|}
\hline Challenge & Responses & \multicolumn{1}{|c|}{} \\
\hline $\begin{array}{l}\text { There are no ICTs available } \\
\text { in the library }\end{array}$ & 280 & 47 \\
\hline $\begin{array}{l}\text { Inadequate skills to search } \\
\text { for information }\end{array}$ & 131 & 22 \\
\hline Slow speed of the Internet & 124 & 21 \\
\hline $\begin{array}{l}\text { Erratic electricity power } \\
\text { supply }\end{array}$ & 51 & 9 \\
\hline Poor network connectivity & 46 & 8 \\
\hline $\begin{array}{l}\text { Electronic library is not } \\
\text { accessible }\end{array}$ & 32 & 5 \\
\hline $\begin{array}{l}\text { Insufficient } \\
\text { systems }\end{array}$ & 15 & 3 \\
\hline $\begin{array}{l}\text { Insufficient funds to use the } \\
\text { Internet }\end{array}$ & 4 & 0.67 \\
\hline $\begin{array}{l}\text { Where ICT exist there is a } \\
\text { dearth of database services }\end{array}$ & & 5 \\
\hline
\end{tabular}

From the table it is clear that in many of the law libraries ICTs, specifically computers and the Internet are lacking as $280(47 \%)$ of the response group indicated it as a challenge. External factors such as low bandwidth resulting in slow download speeds $(131 ; 22 \%)$, erratic power supply $(51 ; 9 \%)$, and poor network connectivity $(46 ; 8 \%)$ were also perceived as problematic by the respondents. Inaccessibility of e-resources or the total lack thereof was also seen as problematic by a smaller number of respondents.

\subsection{Solutions to challenges experienced}

Both the librarians and the students were asked to indicate how they think information service delivery to the students can be improved. The groups responded as follow:

Librarians:

- Providing training to the students on how to use the e-library.

- By providing an alternative source of power e.g. generating plants.

- Providing more digital information resources and employ ICT staff to assist users to effectively make use of the sources.

- $\quad$ Provide adequate funds.

- Installing a separate network for utilisation in the law library. 
- By increasing the level of awareness of the available ICTs and e-resources among students.

- Training and retraining of available staff and the recruitment of professional staff.

- The country needs to improve electricity supply.

- More computers systems should be made available.

- Subscription to more law databases such as Lexis-Nexis and Legalpedia.

- Adequate funding to procure electronic resources, frequent renewal of internet subscriptions and electronic database resources.

Students:

- Better/faster Internet connection (61)

- Improving accessibility to digital sources (41)

- Increased funding by the government to provide ICT hardware and connectivity (39)

- Continual training of the library staff in terms of ICT skills (36)

- Recruit a librarian to man the ICT units (21)

- Provide sufficient electronic devices specifically computers (20)

- Create awareness through the mass media of the existence of the digital sources (20)

- Provide a standby generator for the elibrary (18)

- $\quad$ Provide free access to ICTs (18)

- Maintain ICT equipment (15)

- Build a more spacious room where ICT facilities can be kept (14)

- $\quad$ Proper management of the ICTs (10)

- Digital resources should be maintained (8)

- Procure recent law reports, textbooks and law e-journals (7)

- Students should endeavour to be ICT knowledgeable so that they can easily access the Internet (6)

- The authorities should improve the power supply (5)

- Reduce the rules/regulations on the use of the electronic library (1)

Looking at these solutions there seem to be a number of overlaps between how each group envisage ICT access and utilisation within the libraries can be improved. Common to the responses are the suggestions of finding solutions to the power outages and improved bandwidth to overcome slow downloading speeds. Training of both the staff and the students were also mentioned by both groups.

\section{Discussions}

During the last few years Nigeria, as one of the fastest growing economies on the African continent invest considerable funds towards the development of a viable ICT infrastructure. Seeing it as a means to develop the economy, as well as their human capital, the infrastructure developments has targeted institutions such as educational facilities in order for the academics and students to benefit from the unrivaled access it provides to information.

University managements have equally invested in putting ICT infrastructure in place on their campus. In most cases access to computers and Internet has been provided by way of storing these facilities inside the main libraries. However the findings has shown that provision of these ICTs are unequal on the different campuses surveyed ranging from very good to problematic in some instances. Though most of the campuses had basic infrastructure available for user utilization, all of them seem to be plagued by the same problems, for example erratic power supply, low bandwidth, lack of skills to access the information, and lack of enough computers. These sentiments are echoed by Alhassan and Afolabi [13] and Adekunmisi, Ajala, and Iyoro [14].

Each campus that offers a law program is by law required to also provide an academic law library equipped with an e-library, for the utilization by law students and lecturers. These e-libraries are generally to be equipped with electronic resources, Internet services, computer systems and law databases, such as, Westlaw, Lexis-Nexis, Law Pavilion, Legalpedia and Compulaw [15]. The findings of the study have however shown that some of the law libraries do not have computers available for student utilization and therefore by implication also not any e-resources that they can utilize. Nearly halve of the librarians have also indicated that their libraries did not subscribe to any legal databases. The implication of this is that a large number of the law students do not gain the skills required to find information needed for legal matters, and thus are ineffectual in their information searching once they become qualified lawyers [11].

The question of inaccessibility of Internet facilities has featured in a number of the responses from the students. Not only was the physical hardware in many cases seen as inaccessible, issues such as payment for the utilization of the Internet facilities within the library, as well as the relatively short opening hours of the libraries also contributed towards lack of access. Nwezeh's [16] study found that though students visit their library facilities to 
access the Internet during the library's opening hours they are forced to use cyber cafe's off campus one the library closes. As most of the libraries formalize their subscription registration using the IP address network of the parent organization [17] access to these resources is restricted once a student move offcampus.

\section{Conclusions}

Academic law libraries in Nigeria are in general, still far from e-ready to support the information needs and seeking patterns of the law students. This is not necessarily the fault of the library staffs, which mostly seem to be very supportive of the introduction of e-service delivery [1], but can be attributed to insufficient ICT infrastructure support from the side of the government and the university managers. The erratic power supply is also not within the control of the library staff and until that is addressed by government; ICT related services and its utilization will be poor [18].

Students have indicated that while they are willing to use the available ICTs for the purposes of furthering their studies, the currently available ICTs are not assisting them optimally to utilize them. In cases where especially lack of computers and Internet access are experienced the students have voiced their frustration, and therefore this is an issue that needs immediate response from the management structures.

\section{Recommendations}

It is recommended that both university and academic law libraries invest in digitizing their print materials as much as possible and make it and their databases available through a library website which can be accessed both on and off-Campus. Alternatively these sources can be made available using a localized database.

The use of mobile technology should be encouraged as far as possible since power break downs have less of a negative effect on such technology than using electricity driven devices such as computers.

Both government and university managers should actively seek ways to address issues such as the erratic power supply, low bandwidth, the lack of sufficient ICT facilities such as computers and Internet access and the issue of students having to pay for Internet access whenever they want to utilize it.

Finally it is recommended that academic law libraries liaise with their university managements to convince them of the need of sufficient computers and Internet access in the libraries as it is imperative for law students to be able to seek and retrieve the most current legal information, both for their studies, but also in preparation for their future careers as lawyers.

\section{References}

[1] Speirs, M. (2010). The development of Information and Communication Technologies in Nigerian Libraries. http://eprints.rclis.org/14464/ 2/The_Development_of_Information_and_Communi cation_Technologies_in_Nigerian_Librariesreformatted_single_spaced.pdf

[2]BizAfrica. (2013) "Nigerian ICT Ministry outlines priorities." http://www.biztechafrica.com/ article/nigerian-ict-ministry-outlines-priorities/5070/ (25 May 2013).

[3]Foster, V and Pushak, N. (2011) Nigeria's Infrastructure: a Continental Perspective, http://papers.ssrn.com/sol3/papers.cfm?abstract_id=1 871582 (24 May 2013).

[4]Orange.com. (2013) France Telecom-Orange Announces the Launch of Service for the ACE Submarine Cable in the First 13 Countries. http://www.orange.com/en/press/press-releases/ press-releases-2012/France-Telecom-Orangeannounces-the-launch-of-service-for-the-ACEsubmarine-cable-in-the-first-13-countries (6 July 2013).

[5] N.P. Ololube, A.E. Ubogu, and D.E. Egbezor. "ICT and Distance Education Programs in a SubSaharan African Country: A Theoretical Perspective." Journal of Information Technology Impact, 7(3), 2007, pp. 181-194.

[6] New Media and Development Communication. (n.d.) "Nigeria: the Long Road Ahead" http://www.colombia.edu/itc/sipa/nelson/newmediad ev/Nigeria.html (22 May 2013).

[7] Uzor, B. (2012) Nigeria's uptake of ICTs grows by $0.18 \%$. http://www.businessdayonline.com/ NG/index.php/news/284-breaking-news/47522nigerias-uptake-of-icts-grows-by-018 (22May2013).

[8]HumanIPO. (2012). "0.18 percent growth in Nigeria ICT, ITU report”.

http://www.humanipo.com/news/2275/018-percentgrowth-in-Nigeria-ICT-ITU-report/ (9 April 2013).

[9] Akintunde, S.A. (2006) "State of ICTs in tertiary institutions in Nigeria: Window on the universities." http://dspace.unijos.edu.ng/bitstream/10485/417/1/St ate $\% 20 \mathrm{of} \% 20 \mathrm{ICTs} \% 20 \mathrm{in} \% 20$ Tertiary\%20Institution s\%20Window\%20on\%20the\%20Universities.pdf [10]D.E. Krubu and K.E. Osawaru. (2011). "The Impact of Information and Communication 
Technology (ICT) in Nigerian University Libraries", Library Philosophy and and Practice: http://www.webpages.uidaho.edu/ mbolin/krubuosawaru.htm (22 August 2013).

[11] V. Lawal, C. Stlwell, R. Kuhn and P. Underwood. (2012) "The Legal Profession in Nigeria and the Need for Skill Competencies: An Examination of Current Changes in the Legal Education System" Paper presented at SCECSAL XXth Conference, Nairobi, Kenya 4-8 June 2012.

[12] A.A. Oba. "Towards regaining learning and correcting in the legal profession in Nigeria". CALS: Review of Nigeria law and practice, 1(1), 2007, p. 14-27.

[13] Alhassan, J.A. and Afolabi, M. (2012) "The Use of Information and Communication Technology in Agricultural Research in Nigerian Universities", NLA Quarterly:

http://unllib.unl.edu/LPP/PNLA\%20Quarterly/alhass an-afolabi76-3.htm (24 October 2013).

[14] S.R. Adekumisi, E.B. Ajala, and A.O. Iyoro. (2013) "Internet Access and Usage by Undergraduate Students: A Case Study of Olabisi Onabanjo University, Nigeria”, Library Philosophy and Practice:http://digitalcommons.unl.edu/ cgi/viewcontent.cgi? article $=2191 \&$ context $=$ libphilpr ac\&sei-

redir=1\&referer=http $\% 3 \mathrm{~A} \% 2 \mathrm{~F} \% 2 \mathrm{Fsearch}$.yahoo.co $\mathrm{m} \% 2$ Fsearch $\% 3 \mathrm{Fp} \% 3 \mathrm{DAdekunmisi} \% 252 \mathrm{C} \% 2 \mathrm{BAjal}$ a\%252C\%2Band $\% 2 B I y o r o \% 26 f r \% 3 D g r e e n t r e e \_i e 2$ $\% 26$ ei\%3Dutf-

8\%26ilc\%3D12\%26type\%3D827316\#search=\%22A

dekunmisi\%2C\%20Ajala\%2C\%20Iyoro\%22

October 2013)

[15] N.B. Ossai. "How law students utilize information resources: A case study of the University of Benin, Benin City, Nigeria". International Journal of Library and Information Scienc,. 3 (1) 2011, pp. $1-14$.

[16] Nwezeh. C.M.T. (2010) "The Use of ICT in Nigerian Universities: A Case Study of Obafemi Awolowo University, Ile-Ife", Library Philosophy and Practice, 2010: http://unllib.unl.edu/LPP/ nwezeh3.htm (17 October 2013).

[17]Armstrong, E.A., Croft, V.F., Kok, V.T. and Lener.E.F. (2003) "Electronic Resources Access: Issues and Resolutions in Two Academic Libraries." http://research.wsulibs.wsu.edu/xmlui/bitstream/hand le/2376/2025/Armstrong\%20Electronic\%20resource s.pdf?sequence $=1$ (24 October 2013)
[18] Okiy, R.B. (2012) "Globalization and ICT in Academic Libraries in Nigeria: The Way Forward". http://unllib.unl.edu/LPP/okiy.htm 